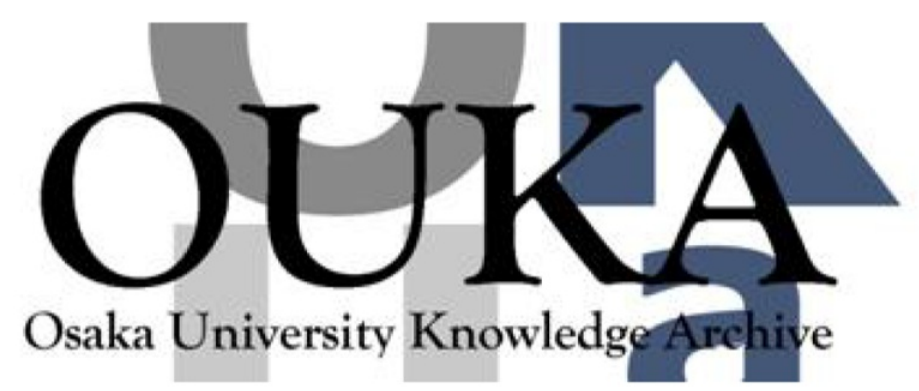

\begin{tabular}{|c|c|}
\hline Title & $\begin{array}{l}\text { エイリアスフローグラフを用いたオブジェクト指向 } \\
\text { プログラムのエイリアス解析手法 }\end{array}$ \\
\hline Author (s) & 大畑，文明；近藤，和弘；井上，克郎 \\
\hline Citation & $\begin{array}{l}\text { 電子情報通信学会論文誌D-I. J84-D-I(5) p. 443- } \\
\text { p. } 453\end{array}$ \\
\hline Issue Date & $2001-05-01$ \\
\hline oaire:version & VoR \\
\hline URL & https://hdl. handle. net/11094/26447 \\
\hline rights & copyright $\odot 2001$ IEICE \\
\hline Note & \\
\hline
\end{tabular}

Osaka University Knowledge Archive : OUKA

https://ir. Library. osaka-u. ac. jp/

Osaka University 


\section{エイリアスフローグラフを用いたオブジェクト指向プログラムの エイリアス解析手法}

大畑 文明 ${ }^{\dagger}$ 近藤 和弘 ${ }^{\dagger}$ 井上 克郎 ${ }^{\dagger}+\dagger$

Alias Analysis Method for Object Oriented Programs Using Alias Flow Graphs

Fumiaki $\mathrm{OHATA}^{\dagger}$, Kazuhiro KONDOU ${ }^{\dagger}$, and Katsuro INOUE ${ }^{\dagger}, \dagger^{\dagger}$

あらまし プログラムテキスト上の式 (または部分式) の対が同一のオブジェクト (メモリ領域) を指す場合， 光れらの式はエイリアス関係にあるという.これらは，引き数の参照渡し，参照変数，ポインタを介した間接参 照などで生じる . 既存のエイリアス解析手法は, 解析結果の再利用が不十分で , オブジェクト指向プログラムの もつ再利用性がエイリアス解析に生かされていない，また，エイリアス解析手法の提案は今までいろいろなされ ているが, 実用的なツールはあまり知られていない，本研究では，エイリアス解析結果の再利用及びモジュール 化を考慮した , オブジェクト指向プログラムに対するエイリアス解析手法を提案する . 本手法を実現したJAVA エイリアス解析ツールは , JDK (JAVA Developers's Kit) 付属クラスライブラリなどの大規模プログラムを実 用的な時間で解析することができる .

キーワード エイリアス，モジュール化，オブジェクト指向プログラム，JAVA

\section{1. まえがき}

プログラムテキスト上の式 (または部分式) の対が 同一のオブジェクト (メモリ領域) を指す場合，乥れ らの式はエイリアス関係 (Alias Relation) にあると いう.エイリアス関係は, 引き数の参照渡し, 参照変 数, ポインタを介した間接参照などによって生じる. エイリアス関係は同值関係であり，乥の同值類をエイ リアス集合 (Alias Set) と呼ぶ.また , プログラムを 静的に解析しエイリアス集合を求めることをエイリア ス解析 (Alias Analysis) といい, コンパイル時の最 適化 [1]や，プログラムスライス (Prgram Slice) [13] の計算に欠くことのできないものである .

また，現在のプログラム開発環境において，Cなど の手続き型言語だけでなく，JAVA [7]，C++ [3] 等い わゆるオブジェクト指向言語の利用が高まっている . オブジェクト指向言語には, 従来の手続き型言語には ないクラス, 継承, 動的束縛, ポリモルフィズムなど

\footnotetext{
$\dagger$ 大阪大学大学院基礎工学研究科, 豊中市
}

Graduate School of Engineering Science, Osaka University, Toyonaka-shi, 560-8531 Japan

†奈良先端科学技術大学院大学情報科学研究科, 生駒市

Graduate School of Information Science, Nara Institute of Science and Technology, Ikoma-shi, 630-0101 Japan
新しい概念が導入されており，乥れらに対応したエイ リアス解析手法が提案されている [14] .

しかし，既存のエイリアス解析手法は，解析手法を オブジェクト指向言語に対応させたにすぎず，解析結 果兴のものの再利用性, モジュール性は満たされてい ない . プログラムの大規模化 , プログラムの再利用人 の関心が高まる現在，これらの特性を満たすエイリア ス解析手法か望まれる.

本研究では, 再利用性, モジュール性を考慮したエ イリアスフローグラフによるエイリアス解析手法の提 案を行う．また，提案手法をJAVA エイリアス解析ツー ルとして実装しその有効性を評価する . 本ツールは， 近年ソフトウェア開発言語として多く利用されてい るJAVA を対象としており，JDK (JAVA Developers's Kit) 付属クラスライブラリなどの大規模プログラム に対しても害用的な時間で解析することができる．

以降，2.ではエイリアス解析及びオブジェクト指向 プログラムに対する解析について説明する．3. で手法 の提案を行う . 4. でJAVA エイリアス解析ツールによ る手法の実験的評価を行い，5. で考察する.最後に 6. でまとめと今後の課題について述べる . 


\section{2. オブジェクト指向プログラムにおけるエ イリアス解析}

\section{1 エイリアス解析}

エイリアス解析は, 大きくFIエイリアス解析 (FlowInsensitive Alias Analysis) (以降, FI 解析と略す), FS エイリアス解析 (Flow-Sensitive Alias Analysis) (以降, FS 解析と略す) の二つに分けることができる . 以下，光れ光れを図 1 を用いて簡単に説明する。

[Flow-Insensitive (FI) エイリアス解析]

FI エイリアス解析 [2], [12] とは , 各プログラム文の 実行順を考慮しないエイリアス解析手法をいい，エイ リアスグラフを利用する.図 1 (a) に変数 c (太枠部) の FIエイリアス (網掛部) を, 図 1 (c) に光の計算 に用いたエイリアスグラフを示す.エイリアスグラフ は無向グラフであり, 節点はメモリ領域を指し得る変 数及び式を，辺は（代入や引き数の参照渡しなどによ り) 節点間に直接のエイリアス関係があることを表す． 文 7 の変数 $\mathrm{c}$ に関するエイリアスを求める場合, エイ リアスグラフの変数 $\mathrm{c}$ 節点から到達可能な節点は $\{\mathrm{a}$, b, new Integer(1), new Integer(2))\} であり，網掛 部が求めるエイリアスとなる .

[Flow-Sensitive (FS) エイリアス解析]

FS エイリアス解析 [9], [16] とは, プログラム文の 実行順を考慮したエイリアス解析手法をいい, 到達 エイリアス集合 (Reaching Alias Set) を利用する. 図 1 (b) に変数 c (太枠部) の FS エイリアス (網掛 部) を, 図 $1(\mathrm{~d})$ に炎の計算に用いた到達エイリアス 集合を示す. 到達エイリアス集合 $R A(s)$ の要素は文 $s$ の実行直前において成立しかつ文 $s$ において識別子
を介して参照可能なエイリアス集合であり，光の集合 の各要素は (文番号, 式) の組で表される.文 7 の変 数 c に関するエイリアスを求める場合， $R A(7)$ から 識別子 c を含むエイリアス集合を探索する . 変数 c は 集合 $\{(6, \mathrm{c}),(2, \mathrm{a}),(6, \mathrm{a}),(2$, new Integer $(1))\}$ に 含まれており, 網掛部が求めるエイリアスとなる .

[FI エイリアス解析と FS エイリアス解析]

FS 解析はプログラム文の実行順を考慮しているた め, FI 解析と比較し時間計算量, 空間計算量を必要と するが, 解析の精度は高く, 実際に図 1 においても光 の差は顕著である . 両者の詳細な比較は [11] でなされ ており, 本研究では解析精度を重視していることから FS 解析に着目する .

2.2 オブジェクト指向プログラムにおけるエイリ

\section{アス解析}

既存のオブジェクト指向プログラムにおけるエイリ アス解析手法は，既に提案されている手続き型言語の エイリアス解析手法をオブジェクト指向言語に拡張し たものとなっているが, 弚れらに関していくつかの視 点から考察を行う.

\section{[FS 解析の問題]}

手続きを含むプログラムを解析する場合 , 到達エイ リアス集合を用いた FS 解析では , すべての実行 (手 続き呼出し）経路をたどりながら到達エイリアス集合 を計算しなければならない．また, 再帰呼出しが存在 する場合，エイリアス集合が収束するまで再帰経路を 解析し続ける必要がある．これは, 解析結果がエイリ アス集合の形で保持されていることに起因している． つまり，ある時点でエイリアス集合に変化が起こった とき, 光の変化の影響を受ける可能性のある到達エイ

$$
\begin{aligned}
& \text { 1: Integer } \mathrm{a}, \mathrm{b}, \mathrm{c} ; \\
& \text { 2: } \mathrm{a}=\text { new Integer(1); } \\
& \text { 3: } \mathrm{b}=\text { new Integer }(2) ; \\
& \text { 4: } \mathrm{c}=\mathrm{b} ; \\
& \text { 5: System.out.println(c); } \\
& \text { 6: } \mathrm{c}=\mathrm{a} ; \\
& \text { 7: System.out.println( }(\mathrm{d}) ;
\end{aligned}
$$

(a) FI エイリアス解析

$$
\begin{aligned}
& \text { 1: Integer } a, b, c ; \\
& \text { 2: } a=\text { new Integer }(1) ; \\
& \text { 3: b = new Integer }(2) ; \\
& \text { 4: c = b; } \\
& \text { 5: System.out.println(c); } \\
& \text { 6: c = a; } \\
& \text { 7: System.out.println(d); }
\end{aligned}
$$

(b) FS エイリアス解析

\section{new Integer(1)|-(a)-(C)-b-new Integer(2)}

(c) エイリアスグラフ

\begin{tabular}{cc}
\hline 文 $(\mathrm{s})$ & 到達エイリアス集合 $(R A(s))$ \\
\hline 1 & $\phi$ \\
2 & $\phi$ \\
3 & $\{(2, \mathrm{a}),(2$, new Integer $(1))\}$ \\
4 & $\{(2, \mathrm{a}),(2$, new Integer $(1))\}$, \\
& $\{(3, \mathrm{~b}),(3$, new Integer $(2))\}$ \\
5 & $\{(2, \mathrm{a}),(2$, new Integer $(1))\}$, \\
& $\{(4, \mathrm{c}),(3, \mathrm{~b}),(4, \mathrm{~b}),(3$, new Integer $(2))\}$ \\
6 & $\{(2, \mathrm{a}),(2$, new Integer $(1))\}$, \\
& $\{(4, \mathrm{c}),(5, \mathrm{c}),(3, \mathrm{~b}),(4, \mathrm{~b})$, \\
& \\
7 & $\{(6, \mathrm{c}),(2, \mathrm{a}),(6, \mathrm{a}),(2$, new Integer $(1))\}$, \\
& $\{(3, \mathrm{~b}),(4, \mathrm{~b}),(3$, new Integer $(2))\}$ \\
\hline
\end{tabular}

(d) 到達エイリアス集合

図 1 FI エイリアス解析と FS エイリアス解析

Fig. 1 FI alias analysis and FS alias analysis. 
リアス集合をもつ文すべてに弚の変化を伝搬させ , 各 文の到達エイリアス集合を再計算しなければならない ためである .

\section{[解析結果の再利用]}

到達エイリアス集合 $R A(s)$ は文 $s$ が存在するプロ グラム全体を解析することにより導出されたものであ るため, 別の文 $t$ か変更されたとき, $R A(s)$ を再計算 しなければならない場合が多く存在する．これは，エ イリアス解析結果のモジュール性, 独立性が満されて いないことに起因する .オブジェクト指向プログラム では, 継承機能など, 言語自身が再利用を考慮したも のとなっているため, 記述されたクラスの利用範囲が 特定のプログラムにとどまらない . また , 上位クラス であるほど光の属性やメソッドは汎化されたものとな り，一度定義されると変更されることは少ない，关の ため, 解析結果のクラスやメソッド単位でのモジュー ル化は, 再計算コストの削減に有効であると考えて いる。

[同一クラスの異なるインスタンス属性の取扱い]

オブジェクト指向プログラムでは, 異なるオブジェ クト間での状態 (属性) と振舞い (メソッド) は独立 であるため, 图 2 の例では $\{\mathrm{x} . \mathrm{s}, \mathrm{A}: \mathrm{s}\}$, $\{\mathrm{y} . \mathrm{s}, \mathrm{A}: \mathrm{s}\}$ が 弚れ光れエイリアス集合といえるが，同一クラスのイ ンスタンスが爫の内部情報を共有する場合，\{x.s, y.s, $\mathrm{A}: \mathrm{s}\}$ がエイリアス集合とみなされるため, 解析精度 の低下につながる .このため，インスタンスごとにク ラス内部のエイリアス情報をもたせる手法が考えられ るが, 単純にインスタンスの数だけエイリアス情報を 生成すると多大な空間コストを要する，光こで, 存在 するエイリアス関係を

- 内部エイリアス関係 (Inner Alias Relation) 同 一クラスのインスタンス間で共通なエイリアス関係

- 外部エイリアス関係 (Outer Alias Relation) 同一クラスのインスタンス間で独立なエイリアス関係 に分け, 内部エイリアス関係のみ前もって解析し, 外 部エイリアス関係は必要に応じて逐次導出する手法が
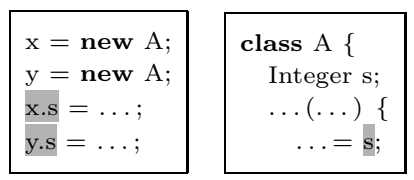

图 2 オブジェクト指向プログラム (JAVA) Fig. 2 Object oriented program (JAVA).
考えられる．

3. エイリアスフローグラフ（ AFG）を用 いたエイリアス解析手法

本研究では, 前章で述べた再解析コストの軽減, エ イリアス解析結果のモジュール化, 内部エイリアス関 係及び外部エイリアス関係の抽出のための，

(1) エイリアスフローグラフ (AFG) 構築法

(2) AFGによるエイリアス計算手法 の提案を行う . エイリアスフローグラフ (Alias Flow Graph , AFG) は, FS エイリアス関係を無向グラフ で表現したものであり，FS エイリアスの計算をグラ フの到達問題に置き換える . 本章で述べるアルゴリズ ムはJAVA を前提に, 参照型の式 (参照变数, インス タンス生成式など）によるエイリアスを対象としてい るが, ポインタ変数の間接参照によるエイリアスにも 拡張可能であり，5.2 で簡単に述べる．

$\mathrm{AFG}$ によるエイリアス解析手法は以下四つのフェー ズで構成される .

Phase 1：AFG 節点 (オブジェクトへの参照) の 抽出

Phase 2: AFG 辺 (直接のエイリアス関係) の抽出 Phase 3: メソッド呼出しグラフの構築

Phase 4 : エイリアス計算

クラス,メソッド単位で到達エイリアス集合に基づ く FS エイリアス解析を行い, クラス AFG (Class

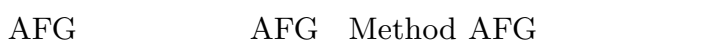
構筑する (Phase 1〜2). 各 AFG は独立したモジュー ルとして存在し, 対応するクラス, メソッドが更新さ れない限り不変であり, 2 次媒体への記憶及び关の再 利用が可能である.AFG は内部エイリアス関係のみ 保持しており, 外部エイリアス関係はユーザからの要 求があったとき逐次解析する (Phase 4).

以降, メソッドのない単一プログラム (図 3), 複数 メソッドで構成されたプログラム (図 8) を例に用い ながら各フェーズを順に説明する．

\subsection{Phase 1：AFG 節点の抽出}

AFG 節点 (AFG Node) は, 文番号とオブジェクト への参照式の組である .ここでいうオブジェクトへの 参照式とは, 参照型の式を指し, 参照変数及びインス タンス生成式もこれに含まれる．また，これらの節点 を特に AFG 標準節点 (AFG Normal Node) と呼ぶ。

図 3 の文番号 3 の b は参照変数であるためオブ ジェクトへの参照式に該当し, $\operatorname{AFG}$ 節点 $(3, \mathrm{~b})$ が生 
表 1 特 殊 節 点

Table 1 AFG special node.

\begin{tabular}{|c|c|}
\hline 特殊節点 & 概要 \\
\hline Actual-Alias-in (AA-in) & 実エイリアス引数 (実引数により, メソッドに渡されるエイリアス) \\
\hline Formal-Alias-in (FA-in) & 仮エイリアス引数 (仮引数により, メソッドに渡されるエイリアス) \\
\hline Actual-Alias-out (AA-out) & 実エイリアス引数 (実引数により, メソッド呼出し元に渡されるエイリアス) \\
\hline Formal-Alias-out (FA-out) & 仮エイリアス引数 (仮引数により, メソッド呼出し元に渡されるエイリアス) \\
\hline Method-Alias-out (MA-out) & 戻りエイリアス値 (戻り値により, メソッド呼出し元に渡されるエイリアス) \\
\hline Method & $\begin{array}{r}\text { メソッド呼出し (メソッドの戻り值により, メソッド呼出し元に渡されるエイリアス， } \\
\text { AA-in (out) 節点の親節点) }\end{array}$ \\
\hline Instance-Alias-in (IA-in) & エイリアス属性 (属性により，メソッド内に渡されるエイリアス) \\
\hline Instance-Alias-out (IA-out) & エイリアス属性 (属性により, メソッド外に渡されるエイリアス) \\
\hline
\end{tabular}

1: Integer $\mathrm{a}=$
$\quad$ new Integer $(0) ;$
2: Integer $\mathrm{b}, \mathrm{c} ;$
3: $\mathrm{b}=\mathrm{a} ;$
$4: \mathrm{c}=\mathrm{b}$

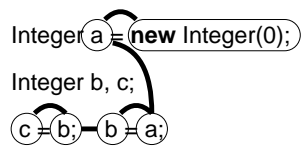

図 3 サンプルプログラム及び光の $\mathrm{AFG}$

Fig. 3 Sample program and its AFG.

成される(注1) . 同樣に, 文番号 1 のnew Integer $(0)$ は インスタンス生成式であるため, $\mathrm{AFG}$ 節点 $(1$, new Integer $(0))$ が生成される .

メソッドのない単一プログラムにおいては, AFG 標準節点のみ用いることで AFG を構築できる.一方， 通常オブジェクト指向プログラムではメソッド引数や インスタンス (クラス) 属性が存在するため, これら を介したエイリアスの受渡しを考慮しなければならな い. 光のため, 表 1 に挙げる AFG 特殊節点 (AFG Special Node) を追加する .

\subsection{Phase 2: AFG 辺の抽出}

AFG 標準辺 (AFG Normal Edge) は ,二つの AFG 節点間で, 同一変数の参照や代入文, パラメータの対 応などによる直接のエイリアス関係が存在するとき引 かれる.複数の AFG 辺で構成された経路は, 2 節点間 の (推移的に成り立つ) 間接のエイリアス関係を表す. また, AFG をオブジェクト指向プログラムに適応 する際, $a . b$ や $c . d()$ のようなインスタンス属性やイ ンスタンスメソッドを表現するために，インスタンス 及び属性 (メソッド) を表す $\mathrm{AFG}$ 節点間に親子関係 を定義する。例えば $a . b$ に関して $, a, b$ に対応する $\mathrm{AFG}$ 節点を乥れ光れ $N_{a}, N_{b}$ とすると, $N_{a}$ は $N_{b}$ の 親節点 (Parent Node) , $N_{b}$ は $N_{a}$ の子節点 (Child Node) となり, $N_{a}$ から $N_{b}$ に対し有向辺が引かれる (このような辺を $\mathrm{AFG}$ 特殊辺 (AFG Special Edge) と呼ぶ）. 図 9 に关の具体例 (破線の有向辺) を示す.

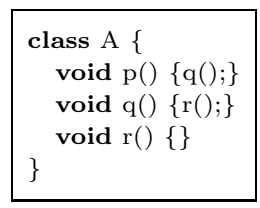

(a) Class A

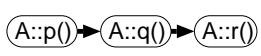

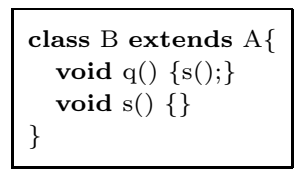

(b) Class B
$A:: p() \rightarrow B:: q() \rightarrow B:: s() \quad A:: q()$

図 4 サンプルプログラム及び光の $\mathrm{MFG}$

Fig. 4 Sample program and its MFG.

この関係はエイリアス計算時 (Phase 4) に利用され る.このような節点間の親子関係は Method 節点と AA-in (out) 節点間にも存在し，これらに対しても同 樣に $\mathrm{AFG}$ 特殊辺を引く.

3.3 Phase 3: メソッド 呼出しグラフの構築

メソッド呼出しグラフ (Method Flow Graph, $\mathrm{MFG}$ ) とは, クラス中に存在する (同一インスタ ンス) メソッド間の呼出し関係を有向グラフで表現し たものである . MFG の各節点を MFG 節点 (MFG Node) と呼び, メソッドを表す .メソッド A がメソッ ド B を呼ふ湯合，A，B に対応する MFG 節点を光

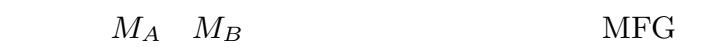
(MFG Edge) が節点 $M_{A}$ から節点 $M_{B}$ に引かれる

図 4 にサンプルプログラム及び兴の MFG を示す. $\mathrm{B}$ クラスではメソッド $\mathrm{p}$ は定義されておらず , シグニ チャ $\mathrm{p}()$ に対するメソッドは $\mathrm{A}: \mathrm{:p}()$ となる . B クラス の MFG 構築の際には, B クラスが継承したメソッド $\mathrm{A}:: \mathrm{p}()$ はシグニチャ $\mathrm{q}()$ のメソッドを呼び出している が , 弚れは $\mathrm{B}:: \mathrm{q}()$ でありメソッド $\mathrm{A}:: \mathrm{q}()$ ではないこ とに留意する必要がある。

(注1)：本論文に図示されている AFG に関して，AFG 節点のラベル には文番号が省略されているが, わかりやすいようプログラムテキスト の文字列をグラフ上に補助的に記している . 


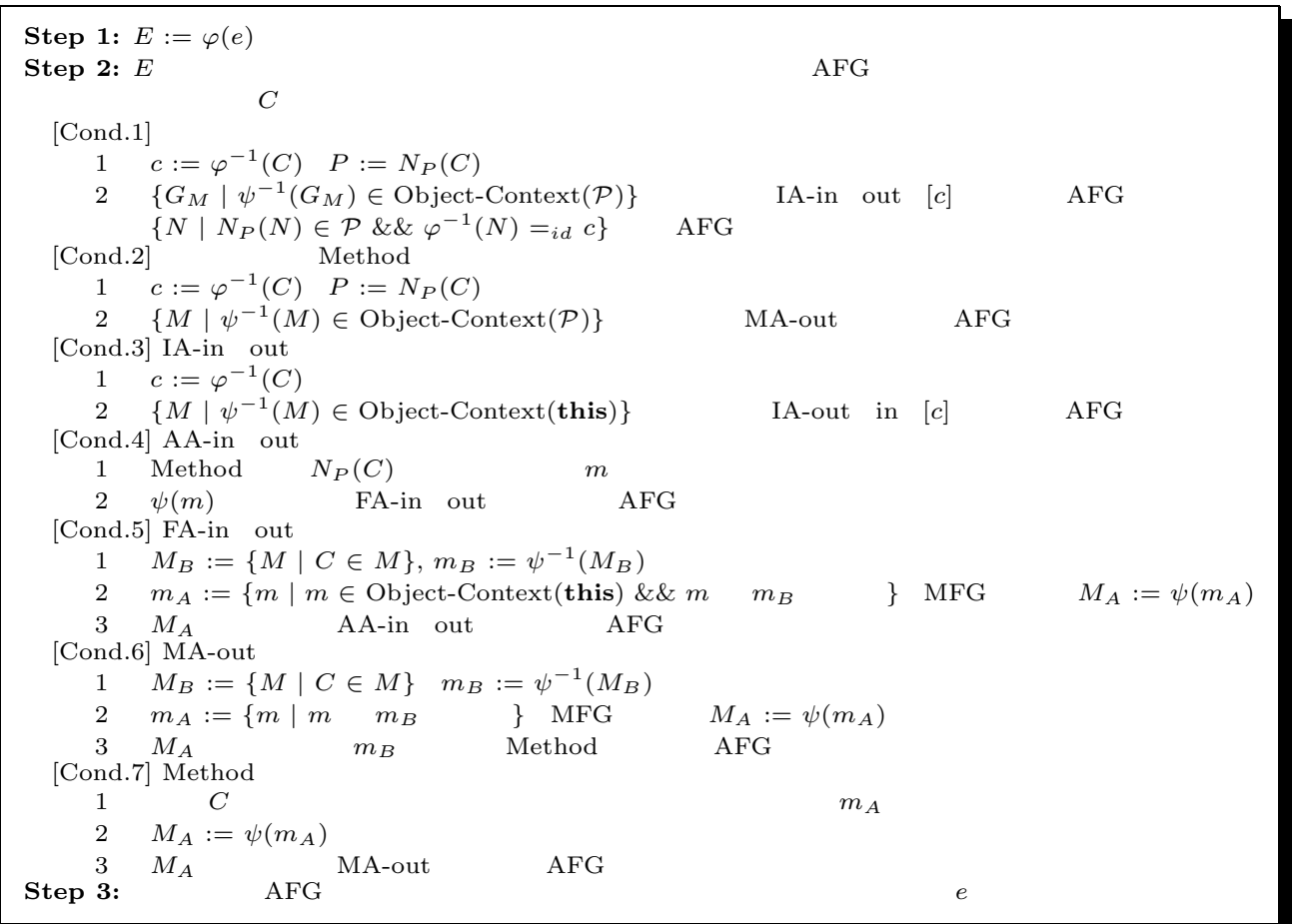

図 5 エイリアス計算アルゴリズム

Fig. 5 Alias calculation algorithm.

\section{4 Phase 4: エイリアス計算}

AFG によるエイリアス計算は以下の方針に基づく . （1） 親節点 $P$ をもつ節点 $C$ のエイリアスを導出 する場合, まず $P$ のエイリアス計算問題を解決させ (これにより,エイリアス解析対象が特定インスタン スに限定され,$P$ の型及び後述するオブジェクトコン テクストが導出される), 兴の結果をもとに $C$ のエイ リアス計算を行う

(2) MA-out や FA-in (out) 節点など , メソッド 間をまたぐエイリアス関係の導出の際には, MFGを 用いて呼出し先 (呼出し元) メソッドを探索し, 対応 する Method 節点や AA-in (out) 節点から AFG 辺 をたどる

アルゴリズムの詳細は図 5 に，また享の中で利用す る式の定義を図 6 に示す.

\section{[オブジェクトコンテクスト]}

$\mathrm{AFG}$ を用いて導出されたエイリアス集合 $\mathcal{P}$ に関す るオブジェクトコンテクスト (Object Context) とは , $\mathcal{P}$ に属する節点の子節点として存在する Method 節点 から導出される, $\mathcal{P}$ か直接若しくは間接的に呼び出す可

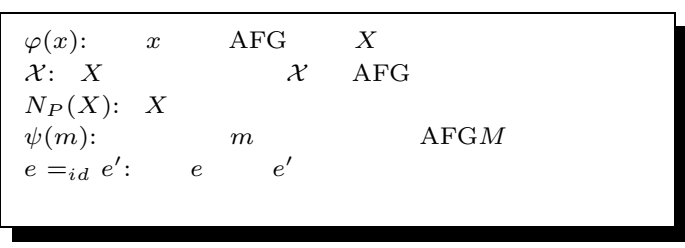

图 6 定義

Fig. 6 Definitions.

能性のあるメソッド集合を指し, Object-Context $(\mathcal{P})$ と表す.

直接呼び出されるメソッドとは, Method 節点に対 応するメソッドを指す ${ }^{(\text {注2) }}$. 間接的に呼び出されるメ ソッドとは, 直接呼び出されるメソッドが内部で呼び 出す可能性のある同一インスタンスのメソッドを指し， MFG を用いて導出する.

$$
\text { またオブジェクトコンテクストは, FS オブジェクト }
$$

(注2) : メソッドのオーバライドが行われた場合，P の型が唯一に特定 できなければ同一シグニチャに対してメソッドが複数存在する可能性が ある。 


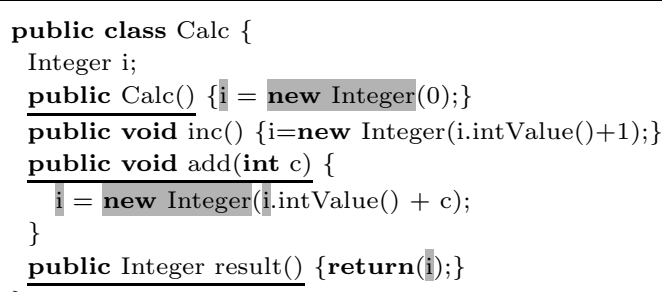

(a) FI オブジェクトコンテクスト

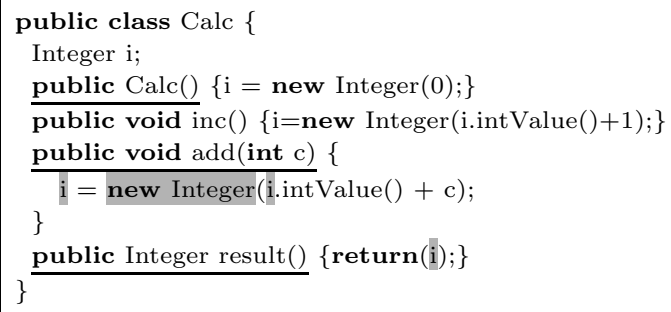

(b) FS オブジェクトコンテクスト

图 7 オブジェクトコンテクスト

Fig. 7 Object context.

コンテクスト (Flow Sensitive Object Context) , FI オブジェクトコンテクスト (Flow Insensitive Object Context）に分けられる . 前者はメソッドの実行順を 考慮するが, 後者は考慮しない. 兴のため, FS オブ ジェクトコンテクストは FI オブジェクトコンテクス トより正確なエイリアス情報を抽出することができる． 例として，図 7 において Calc::Calc(), Calc::add(), Calc::result() か训順に呼ばれたときのreturn(i) に関す るエイリアス計算を挙げる. 図 7 (b) はメソッド実行 順を考慮しているため, 図 7 (a) と比較して钅のエイ リアス集合は小さく, Calc::Calc() メソッド内の 2 式 i , new Integer が除外されているのがわかる.メソッ ド実行順を考慮するには解析コストの増加は避けられ ず，これらはトレードオフの関係となる .なお，本論 文では FI オブジェクトコンテクストを採用している .

\section{5 エイリアス計算例}

エイリアス計算の例として, 図 8 の参照変数 c (太 枠網掛部) のエイリアスの抽出手順を説明する .

(1) 参照变数 c に対応する AFG 節点から $\mathrm{AFG}$ 辺をたどり, Method 節点 result() に到達（図 9)

(2) Method 節点 result() は親節点 b をもつた め, 親節点 $\mathrm{b}$ のエイリアス計算を行い, Method 節点 result() のエイリアス計算に関与するインスタンスを 特定する

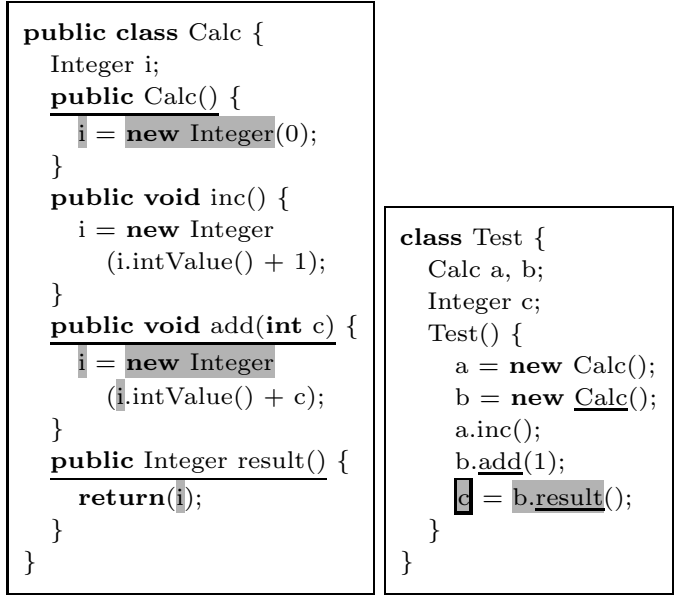

図 8 文 $\mathrm{c}=\mathrm{b}$.result()の $\mathrm{c}$ に関するエイリアス (網掛部)

Fig. 8 Alias set for $\mathrm{c}$ at $\mathrm{c}=$ b.result()(Masked).

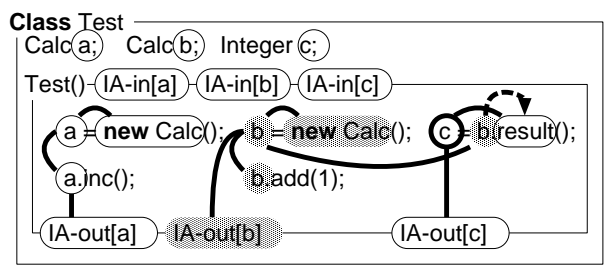

図 9 図 8 の文 c = b.result() のb に関するエイリアス (網掛部)

Fig. 9 Alias set for $\mathrm{b}$ at $\mathrm{c}=$ b.result() in Fig. 8 (Masked).

( a ) 節点 $\mathrm{b}$ のエイリアス $\mathcal{B}$ を計算 (図 9)

( b ) $\mathcal{B}$ に存在するインスタンス生成式から節点 b の型を特定 [Calc クラス]

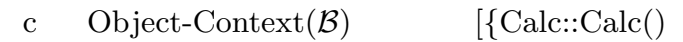
Calc::add(int c) , Calc::result()\}]

( 3 ) 節点 $\mathrm{b}$ は Calc クラスのインスタンスへの参 照であることから，Calc::result() の MA-out 節点か ら AFG 辺をたどる (図 10)

(a) AFG 辺をたどり，IA-in[i]に到達

（b）属性 i のエイリアスに影響を与え得るメ ソッド, すなわち Object-Context(this) = ObjectContext $(\mathcal{B})$ の IA-out [i] 節点から $\mathrm{AFG}$ 辺をたどる (Calc::Calc ()$, \operatorname{Calc::add}()$ も同樣)

図 8 に,c のエイリアス (網掛部) 及び Object$\operatorname{Context}(\mathcal{B})$ (下線部) を示す. Object-Context $(\mathcal{B})$ に 含まれない Calc::inc() はエイリアス計算対象から除 外されているのがわかる. 


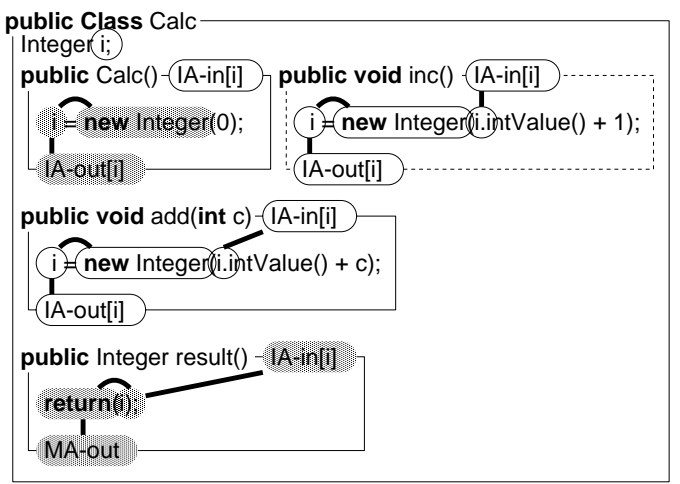

図 10 図 8 の文 $\mathrm{c}=$ b.result() の b.result() に関する エイリアス (網掛部)

Fig. 10 Alias set for b.result() at $\mathrm{c}=$ b.result() in Fig. 8 (Masked).

\section{4. 実験}

提案手法をJAVA を対象言語とするエイリアス解析 ツールとして実装し，本手法の有効性を評価した。解 析アルゴリズムとして , FI オブジェクトコンテクスト を採用している。

4.1 Java エイリアス解析ツール

ツールは解析部 (JAVA エイリアス解析ライブラリ) とユーザインタフェース部 (JAVA エイリアス表示ツー ル) で構成されており，兴の構成を図 11 (a) に示す. 以降, 解析部及びユーザインタフェース部を谷れ光れ 簡単に説明する。

\section{[解析部]}

解析部は C+十で記述されており，libANTLR (字句 解析, 構文解析) (注3) , libjavamm (意味解析), libAFG (エイリアス解析) の三つのライブラリで構成されて いる.これらのライブラリにより, 各JAVA ソースプ ログラムに対して構文解析木, 意味解析木, MFG 及

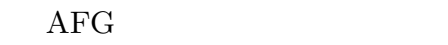

[ユーザインタフェース部]

ユーザインタフェース部は，C+十で記述されてお り Gtk-ー [6] ツールキットを使用している . 兴の機 能には, テキストウィンドウ (図 11 (b) ) 及びエイリ アストリーウィンドウ (図 11 (c)) によるエイリアス 表示, プログラム編集がある . ユーザがあるオブジェ クトへの参照式に関するエイリアスの抽出を指示す ると, ツールはテキストウィンドウ及びエイリアスト リーウィンドウ上に关の解析結果を表示する .

エイリアス集合の導出により，プログラムテキスト はエイリアス集合に含まれるエイリアス部分 (Alias

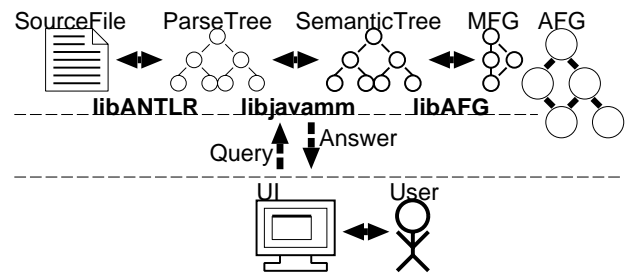

(a) ツール構成

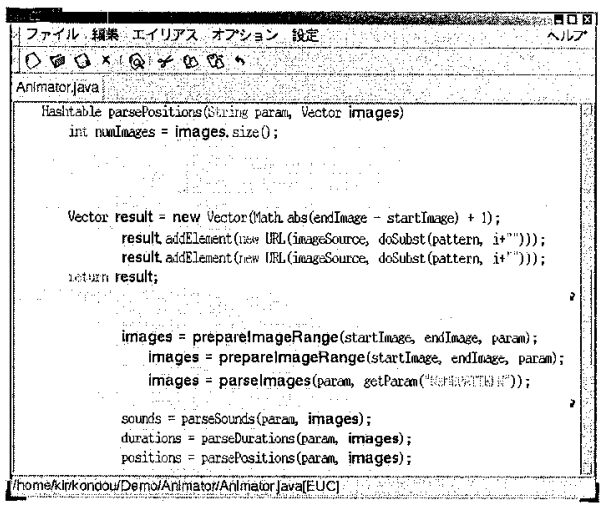

(b) テキストウィンドウ

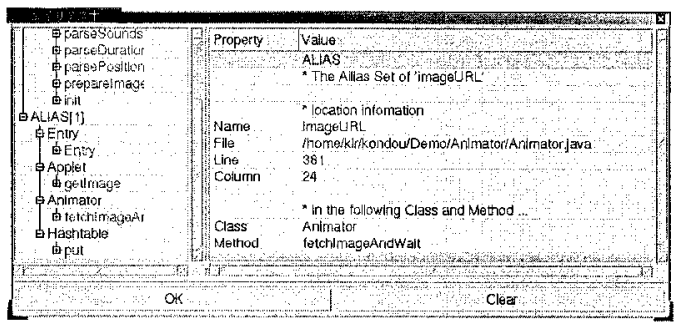

(c) エイリアストリーウィンドウ

図 11 JAVA エイリアス解析ツール

Fig. 11 JAVA alias analysis tool.

part）と，エイリアス集合に含まれない非エイリアス 部分 (Non-alias part) に区分される.テキストウィ ンドウでは, ユーザの視点をエイリアス部分に着目さ せなければならないが, エイリアス部分と非エイリア ス部分の差別化の手段はユーザの目的によって樣々で ある．とりわけ，エイリアスの性質上ソースコード中 に占める割合は非エイリアス部分が圧倒的に多く，光 の視覚化に重点をおく必要がある．本ツールでは目的 に応じた三つの視覚化手法を実現し，弚の一つとして， 図 11 (b) ではエイリアス部分を背景色の変更により， 非エイリアス部分を線分化により差別化を行っている .

(注3)：ANTLR [5] は, 言語 $L$ の文法 $\mathcal{L}$ を与えることで $L$ の字句解 析 , 構文解析ルーチンを $\mathrm{C}++$ 若しくはJAVA で生成するツールである. 
表 2 対象プログラム

Table 2 Target programs.

\begin{tabular}{crrrr}
\hline \multirow{2}{*}{ プログラム } & \multicolumn{2}{c}{ 新規 } & \multicolumn{2}{c}{ 再利用可能 } \\
\cline { 2 - 5 } [J概要] & ファイル & \multicolumn{1}{c}{ 行 } & ファイル & \multicolumn{1}{c}{ 行 } \\
\hline WeirdX & 47 & 16,703 & 815 & 115,977 \\
[X サーバ] & $(5.5 \%)$ & $(12.6 \%)$ & $(94.5 \%)$ & $(87.4 \%)$ \\
ANTLR & 129 & 18,775 & 267 & 33,847 \\
[構文解析生成] & $(32.6 \%)$ & $(35.7 \%)$ & $(67.4 \%)$ & $(64.3 \%)$ \\
DynamicJava & 242 & 32,037 & 825 & 119,564 \\
[インタプリタ] & $(22.7 \%)$ & $(21.1 \%)$ & $(77.3 \%)$ & $(78.9 \%)$ \\
\hline
\end{tabular}

表 3 エイリアス解析時間 (Phase 1〜3) [ms] Table 3 Alias analysis time (Phase $1-3)[\mathrm{ms}]$.

\begin{tabular}{lcr}
\hline \multicolumn{1}{c}{ プログラム } & \multicolumn{1}{c}{ 新規 } & \multicolumn{1}{c}{ 再利用可能 } \\
\hline WeirdX & 14,220 & 100,540 \\
ANTLR & 12,830 & 23,480 \\
DynamicJava & 56,260 & 110,150 \\
\hline \multicolumn{2}{l}{ PentiumIII-667 MHz-512 MB(Linux) }
\end{tabular}

表 4 エイリアス計算時間 (Phase 4) [ms] Table 4 Alias calculation time (Phase 4) [ms].

\begin{tabular}{llr}
\hline \multicolumn{1}{c}{ プログラム } & \multicolumn{1}{c}{ 計算対象クラス } & 計算時間 \\
\hline WeirdX & com.jcraft.weirdx.Client & 0.29 \\
ANTLR & antlr.MakeGrammar & 0.17 \\
DynamicJava & koala.dynamicjava. & 0.07 \\
& interpreter.TypeChecker & \\
\hline
\end{tabular}

また, エイリアス部分は複数メソッドにわたって点 在することが多く, 複数のファイルに及ぶことも少な くない.エイリアストリーウィンドウは , テキストウィ ンドウでは困難なエイリアス部分全体の把握を支援す る.エイリアストリーの各節点は, クラス名 , メソッ ド名 , オブジェクトへの参照式を表す . 図 11 (c) では, 二つのエイリアス集合 (ALIAS[0], ALIAS[1]) のエ イリアストリーが示されており, トリーの各節点を選 択することで対応する要素の名前, 型, 位置などの情 報を得ることができる．

\section{2 計測 方 法}

対象プログラムの概要を表 2 に示す .ここでは, 対 象プログラム自身を新規モジュール, 対象プログラム が利用する JDK 1.2 付属クラスライブラリを再利用 可能モジュールとみなし, 以下の 3 点について検証を 行った .

（1）解析結果のモジュール化による効率化

新規モジュール及び再利用可能モジュールのエイリ アス解析 (Phase 1 3) 時間の比較 (表 3).

(2) AFG によるエイリアス計算時間

対象ファイルに存在するすべての AFG 標準節点か らの平均エイリアス計算 (Phase 4) 時間 (表 4).

（３）同一クラスの異なるインスタンスの属性を区
表 5 エイリアス集合の要素数

Table 5 Size of alias set.

\begin{tabular}{llrc}
\hline \multicolumn{1}{c}{ プログラム } & \multicolumn{1}{c}{ 計算対象クラス } & 非共有 & 共有 \\
\hline WeirdX & com.jcraft.weirdx.Client & 15.37 & 24.54 \\
ANTLR & antlr.MakeGrammar & 5.94 & 18.77 \\
DynamicJava & koala.dynamicjava. & 9.16 & 17.19 \\
& interpreter.TypeChecker & & \\
\hline
\end{tabular}

別することによる解析精度への影響

インスタンス属性に関するエイリアス情報に関し，

・インスタンスごとに区別しない (共有)

・インスタンスごとに区別する (非共有)

の二つの手法を用いて $(2)$ と同樣のエイリアス計算を 行い, 導出されたエイリアス集合の平均要素数を比較 (表 5).

\section{5. 考察}

\section{1 実験データの解釈}

解析結果のモジュール化による効率化 (表 3) に関 して, 到達エイリアス集合のみによるエイリアス解析 では，モジュール単位でエイリアス解析結果を保持す ることができないため, あるモジュールが変更される と光のモジュールが利用する他のモジュールも再解析 の対象にせざるを得ない，本手法では，新たな変更が 加えられず繰り返し再利用されるモジュールを解析し AFG を構築しておくことで, ユーザは新規・更新モ ジュールのみ解析すればよく, 解析コストの削減が得 られる.

到達エイリアス集合のみによるエイリアス解析で は, 解析終了時点ですべてのエイリアス集合が抽出さ れている.提案手法のエイリアス解析過程は, AFG 構築 (Phase 1〜3) 及びAFG によるエイリアス計算 (Phase 4) に区分されており，エイリアス集合を導出 するにはエイリアス計算を行う必要がある．しかし， AFG 構築時間と比較した場合, エイリアス計算に要 する時間コストは小さく，求めるエイリアスが特定の ものに限られている場合やユーザとの対話形式でエイ リアスを求める解析ツールの実現においては, 実用に 十分に足るものであると考えている (表 4).

また本手法では, 同一クラスのインスタンスに共通 するエイリアス関係のみ AFG に保持し，インスタン ス独自のエイリアス関係はエイリアス計算時に導出す る . 本手法の適応により, 同一クラスの異なるインス タンスのエイリアス情報を個別に取り扱うことで精度 の向上が得られている(表 5). 


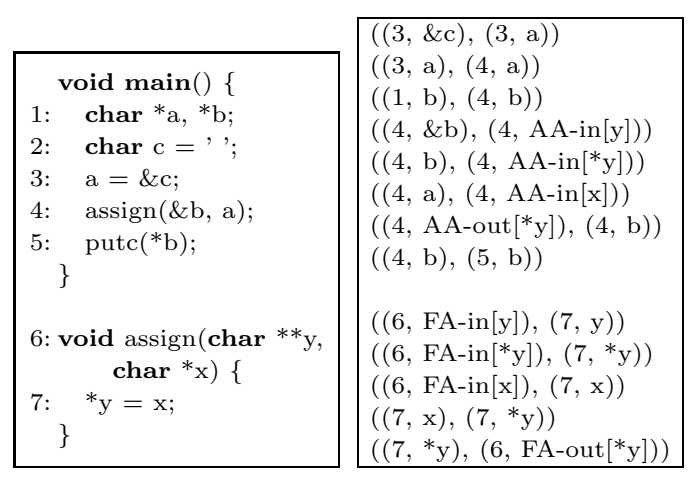

图 12 ポインタ変数をもつ言語 $(\mathrm{C})$ でのエイリアス解析 Fig. 12 Alias analysis for languages with pointer variables like $\mathrm{C}$.

\section{2 ポインタ変数をもつ言語でのエイリアス解析}

3. で述べたアルゴリズムはJAVA のもつ参照型の 式によるエイリアスを仮定したものであったが，C， $\mathrm{C}++$ +どポインタ変数をもつ言語ではポインタ(特 に高階ポインタ) による間接参照を考慮する必要があ る.これは, 引き数として $n$ 階 $(n \geq 2)$ ポインタ変 数を使用することで, たとえ值渡しであっても, 手続 き内で呼出し元のエイリアス関係を変更可能であるこ とによる。

提案手法をポインタに適用するため Phase 1, 2, 4 を拡張する．以下に光の拡張に関して簡潔に述べる。 の抽出

一 Phase 1:AFG 節点の抽出, Phase 2: AFG 辺

参照変数では 1 変数当り一つのエイリアス情報で あつたが, $n$ 階ポインタ変数では 1 変数当り $n$ 個の エイリアス情報を用意する. 図 12 は，C 言語で記述 されたプログラム及び炎こから抽出された直接のエイ リアス関係の集合を示している.手続き $\operatorname{assign}(\mathbf{c h a r}$ ${ }^{* *} \mathrm{y}$, char $\left.{ }^{*} \mathrm{x}\right)$ は 2 階のポインタ変数 $\mathrm{y}$ を使用してお り, 実引き数である\&b について\&b 及び $\mathrm{b}$ に関する エイリアス情報が AA-in 節点として , 仮引き数 $\mathrm{y} に$ ついて $\mathrm{y}$ 及び*y に関するエイリアス情報が FA-in 節 点として，手続き $\operatorname{main}()$ ，手続き $\operatorname{assign}\left(\operatorname{char}{ }^{* *} \mathrm{y}\right.$, $\left.\operatorname{char}^{*} \mathrm{x}\right)$ に乥れ攵れ用意されている．また，b，*y に関するエイリアス情報を呼出し先に反映するため， AA-out，FA-out 節点が光れぞれ追加されている.

— Phase 4 : エイリアス計算

ポインタに関する演算子としては, 間接演算子 ‘ * 及びアドレス演算子' $\&$ ’がある $* x$ は $x$ が指す記憶 領域の内容を, $\& x$ は $x$ の記憶領域の位置を表す.エ
Step 2: $E$ を始点とし, 新たな到達可能節点が見つから なくなるまで AFG 辺を推移的にたどる

加えて, 到達節点 $C$ の種類に応じて以下のような処理 も行う

[Cond.1] 親節点をもつ標準 (インスタンス属性) 節点 :

[Cond.8] '*' 演算子をもつ $\mathrm{AFG}$ 標準節点

(1) $X:=\varphi(x)$ $\left(* x=\varphi^{-1}(C)\right)$ :

(2) $\{\varphi(y) \mid \varphi(\& y) \in \mathcal{X}\}$ から AFG 辺をたどる $\{\varphi(* y) \mid \varphi(y) \in \mathcal{X}\}$ から AFG 辺をたどる

[Cond.9] '\&' 演算子をもつ AFG 標準節点

(2) $\{\varphi(y) \mid \varphi(* y) \in \mathcal{X}\}$ から $\mathrm{AFG}$ 辺をたどる $\{\varphi(\& y) \mid \varphi(y) \in \mathcal{X}\}$ から AFG 辺をたどる

図 13 エイリアス計算アルゴリズム (ポインタ)

Fig. 13 Alias computation algorithm (for pointers).

イリアス計算アルゴリズムをこれらの演算子に対応さ せるため, 図 5 のStep 2 を拡張する.詳細は, 図 13 に示す．

5.3 関連研究

エイリアス解析のモジュール化に関する研究として は $[10],[15]$ がある . 前もってモジュール内のエイリア ス解析を行う点で我々と同じであるが先の計算の手間 は大きくなる .これらの手法では各文の到達エイリア ス集合の要素をエイリアス関係の成り立つ組 $\{(\alpha, \beta)$, $(\gamma, \delta)\}$ で表現している.これは, $\alpha, \beta$ がエイリアス 関係を満たすならば， $(\gamma, \delta)$ がエイリアスとして導出 されることを意味する .このとき， $(\alpha, \beta)$ を $(\gamma, \delta)$ に 対する制約条件という．この制約条件は，本論文でい う間接的なエイリアス関係の成立条件に対応する .

しかし，これらの手法はエイリアス解析のモジュー ル化 (呼出し側モジュールの解析結果に依存しないエ イリアス解析）を実現するため, 各モジュール内での エイリアス解析時に, 対象モジュールから参照可能な 外部変数 (大域変数や仮引き数など) のすべての組合 せを $(\alpha, \beta)$ として与え, 弚のとき成立するエイリア ス組 $(\gamma, \delta)$ を抽出する必要がある.

我々の手法は直接的なエイリアス関係のみを $\mathrm{AFG}$ 辺で表現し，間接的なエイリアス関係は AFG 上での 到達可能性を調べることで得るようにしている．し たがって，モジュール内のエイリアス解析時 (Phase 1〜2) には, 外部変数すべての組合せを想定する必 要はなく, 直接的なエイリアス関係を満たす節点間に $\mathrm{AFG}$ 辺を引くだけでよい .モジュールにまたがる解 
析 (Phase 4) のとき, 外部変数間のエイリアス関係 は到達可能な AFG として与えられる.モジュール内 解析ではエイリアスとして導出されなかった二つの式 が (外部からの影響により) 間接的なエイリアス関係 を満たすかどうかは, 与えられた外部からの AFGを 経由することで到達可能となるかを調べればよい．

また,[10] は手続き型言語に関してのみ論じられて おり, オブジェクト指向言語特有の問題, 例えば本論 文で扱うオブジェクトコンテクストなどは考慮されて いない.[15] は参照変数への代入により発生するエイ リアスを求める方法を提案しており, ポインタ変数に よるエイリアスには触れられていない．また，いずれ の研究もプロトタイプ実装を行っただけで, 実用的な システム構築には至っていない .

一方，今回我々は FI オブジェクトコンテクストを 採用しており, メソッドの呼出し順を考慮している上 記 2 手法と比較して解析精度が低下する場合がある． 精度とコストはトレードオフの関係にあるため一概に 手法の優越を判断することは難しいが, 今後 FS オブ ジェクトコンテクストも加えた相互比較を行いたいと 考えている .

\section{6. むす び}

本研究では, オブジェクト指向言語に対する, 再利 用性，モジュール性を考慮したエイリアスフローグラ フによるエイリアス解析手法の提案を行った .また， 提案手法をJAVA エイリアス解析ツールとして実装を 行い, 弚の有効性を検証した . 今後の課題としては， 既存のエイリアス解析手法とのコストや精度に関する 比較, AFG データベースの構築, 例外処理, スレッ ドへの対応などが挙げられる.

謝辞 本研究は, 栢森情報科学振興財団の補助を受 けている .

\section{文献}

[1] A.V. Aho, R. Sethi, and J.D. Ullman, Compilers: Principles, Techniques, and Tools, Addison-Wesley, 1986.

[2] B. Steensgaard, "Points-to analysis in almost linear time," 23rd Annual ACM SIGACT-SIGPLAN Symposium on the Principles of Programming Languages, pp.32-41, 1996.

[3] B. Stroustrup, The $\mathrm{C}++$ Programming Language, Third edition, Addison-Wesley, 1997.

[4] G. Booch, Object-Oriented Design with Application, The Benjamin/Cummings Publishing Company, 1991.
[5] http://www.ANTLR.org/, ANTLR Website.

[6] http://gtkmm.sourceforge.net/, Gtk--.

[7] J. Gosling, B. Joy, and G. Steele, 村上雅章 (訳), The Java 言語仕樣, 1997.

[8] 片山卓也, 土居範久, 鳥居宏次 (監訳) , ソフトウェアエ 学大事典, 朝倉書店, 1998 .

[9] M. Enami, R. Ghiya, and L.J. Hendren, "Contextsensitive interprocedural points-to analysis in the presence of function pointers," SIGPLAN'94 Conference on Programming Language Design and Implementation, pp.242-256, 1994.

[10] M.J. Harrold and G. Rothermel, "Separate computation of alias information for reuse," IEEE Trans. Software Eng., Special Section of Best Papers of the 1996 International Symposium on Software Testing and Analysis, vol.22, no.7, pp.442-460, 1996.

[11] M. Hind and A. Pioli, "An empirical comparison of interprocedural pointer alias analysis," IBM Research Report \#21058, 1997.

[12] M. Shapiro and S. Horwitz, "Fast and accurate flowinsensitive point-to analysis," 24th Annual ACM SIGACT-SIGPLAN Symposium on the Principles of Programming Languages, 1997.

[13] M. Weiser, "Program slicing," Proc. 5th International Conference on Software Engineering, pp.439449, 1981.

[14] P. Tonella, G. Antoniol, R. Fiutem, and E. Merlo, "Flow insensitive $\mathrm{C}++$ pointers and polymorphism analysis and its application to slicing," Proc. 19th International Conference on Software Engineering, pp.433-443, 1997.

[15] R.K. Chatterjee and B.G. Ryder, "Modular concrete type-inference for statically typed object-oriented programming languages," Department of Computer Science, no.DCS-TR-349, Rutgers University, 1997.

[16] R.P. Wilson and M.S. Lam, "Efficient contextsensitive pointer analysis for C programs," SIGPLAN'95 Conference on Programming Language Design and Implementation, pp.1-12, 1995.

(平成 12 年 7 月 7 日受付, 11 月 6 日再受付)

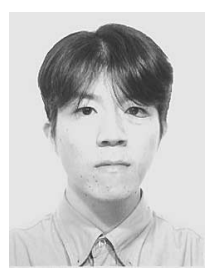

\section{大畑 文明}

平 10 阪大·基礎工・情報中退 . 平 12 同 大大学院修士課程了. 現在, 同大学院博士 課程在学中. プログラム構造解析の研究に 従事. 


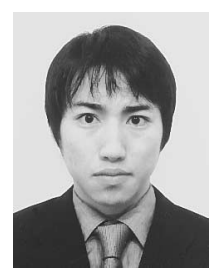

\section{近藤 和弘}

平 12 阪大 · 基礎工 ・ 情報卒 . 現在, 同 大大学院修士課程在学中. プログラム構造 解析の研究に従事 .

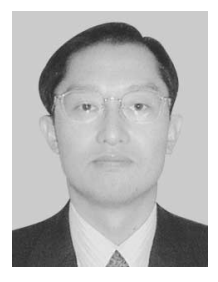

\section{井上 克郎 (正員)}

昭 54 阪大 - 基礎工 - 情報卒. 昭 59 同大 大学院博士課程了. 同年同大 - 基礎工 - 情 報助手. 昭 59 61 ハワイ大マノア校・情 報工学科助教授. 平 1 阪大 - 基礎工 - 情報 講師. 平 3 同学科助教授. 平 7 同学科教 授. 工博. ソフトゥェア工学の研究に従事. 